\title{
Social Media Centrality in Identity (Re)construction in Higher Education
}

\author{
Maria José Sá \\ Dr., CIPES - Centre for Research in \\ Higher Education Policies, Portugal
}

Sandro Serpa

Dr., Department of Sociology, Faculty of Social and Human Sciences, University of The Azores;

Interdisciplinary Centre of Social Sciences - CICS.UAc/CICS.NOVA.UAc; Interdisciplinary Centre for Childhood and Adolescence - NICA - UAc, Portugal

\section{Carlos Miguel Ferreira}

Dr., Interdisciplinary Centre of Social Sciences - CICS.NOVA; ISCTE - University Institute of Lisbon, Portugal

\section{Ana Isabel Santos}

Dr., Faculty of Social Sciences and Humanities, University of The Azores; Interdisciplinary Centre for Childhood and Adolescence -NICA -Uac, Portugal

Doi: 10.36941/jesr-2020-00o2

\section{Abstract}

Social media, including digital social networks, runs through a large part of society. This position paper analyses the social media centrality in identity (re)construction in higher education, seeking to add to the understanding of the social media's role in the identity, both in the individual dimension - of several higher education actors (academics and students) - and in the identity of higher education institutions. In methodological terms, a selection and review of publications addressing this topic were conducted. Results allow concluding that it is critical to consider the growing relevance of digital social networks in shaping these actors' identity, without disregarding the individual situations of great limitation or even rejection by the presence of digital social networks in identity (re)construction. Regarding the implications, at the theoretical level and according to the existing corpus of knowledge, there is a need for further studies to deepen the understanding of this topic. As a practical implication, while the presence of digital social media in human relationships is unavoidable in many instances, the intentional and relevant mobilization of these digital social media is crucial, both for higher effectiveness and efficacy of the academic-student interaction and for the dissemination and positive image of higher education institutions and academics.

Keywords: social media, digital social network, identity (re)construction, digital culture, higher education

\section{Introduction}

Digital social media, as "forms of electronic communication where users can create communities to share information, ideas, pictures, videos and other content" (Rashid, Ahmed, \& Hossain, 2019, p. 36), 
are undoubtedly present in the (professional and personal) daily life of many individuals, sometimes causing a true dependency (Rashid et al., 2019; Golder \& Macy, 2013; Chugh \& Ruhi, 2017; Ferreira \& Serpa, 2018; Gladden, 2019; Longstreet \& Brooks, 2017; Bernardini, 2019; Yavich, Davidovitch, \& Frenkel, 2019).

According to Throuvala, Griffiths, Rennoldson, and Kuss (2019), the relationships that are established through social networks partly reflect "the need for control of content and relationships and to construct social reality along the idealization-normalization continuum" (p. 173). It should be noted, though, that the digital world has features and implications that are not the same as a classic face-to-face interaction with physically present actors (Yavich et al., 2019; Serpa \& Ferreira, 2018).

Watts, Wagner, Velasquez, and Behrens (2017) highlight, however, one of the dark sides of social networks that cannot be forgotten in its various materialized forms - cyberbullying: "as [the] intent to consistently harass another individual to cause harm via any electronic method, including social media, and includes defamation, public disclosure of private facts, and intentional emotional distress" (p. 268).

The field of higher education is not, of course, immune to the presence of social media and social networks (Chugh \& Ruhi, 2017; Donelan, 2015; Rowan-Kenyon \& Alemán, 2016; Kelling \& Kelling, 2013; Zachos, Paraskevopoulou-Kollia, \& Anagnostopoulos, 2018; Taylor \& Francis, 2019; Stathopoulou, Siamagka, \& Christodoulides, 2019). Rowan-Kenyon and Alemán's (2016) perspective points to the fact that social media are unavoidable in higher education, at several levels:

Social media are now important spaces on the higher education landscape, affecting individual and group behavior and campus culture. Consequently, how students use social media to engage with the campus community and to enhance their college experiences is of critical interest to higher education scholars and practitioners. Institutional leaders and campus practitioners are also in need of research and scholarship on social media to determine effective practices. How can an institution employ social media to affect instruction, student services, and institutional effectiveness in an increasingly competitive market where social media use is expected by stakeholders? Thus, knowledge of the scholarship on social media and its implications for higher education practice is necessary for all higher education administrators, staff and faculty, and student affairs and student services practitioners to be innovative in their practice (p. 7).

However, special attention is ascribed to the use of social media by students (Yavich et al., 2019; Stathopoulou et al., 2019). In this sense, Hashim, Rashid and Atalla (2018) maintain that the existing body of knowledge on the presence and influence of social media in the context of higher education also needs to be thoroughly analyzed to be well understood in several aspects, such as: "examine the overall suitability of social media as a teaching and learning platform", "understanding the management aspects of adopting social media at an institutional level", "identify the suitable assessments styles and teaching pedagogy that goes along with teaching activities using social media application", "analyze the performance of social media as teaching and learning tools by giving better analytical insights to both faculty members and students on their performance", "build up a stronger underlying basis of research on this topic by supporting it with theories", "integrate quantitative and qualitative research methodology with data science approaches (i.e., text mining, sentiment analysis)" (pp. 15 and 16).

This position paper emerges in this context. Taking on the form of an essay, it seeks to be a contribution to the understanding of social media centrality in identity (re)construction in higher education, a subject that has received little attention by researchers, as sustained by Yavich et al. (2019), Rowan-Kenyon and Alemán (2016), Stathopoulou et al. (2019) and Hashim et al. (2018).

This paper seeks, thus, to add to the understanding of the role of social media in the identity, both in the individual dimension of several higher education actors (academics and, more importantly, students) and in the identity of higher education institutions. To fulfil this goal, the paper is structured according to the following sections: Methods, Social media and identity, Social media and identity in Higher Education - which is sub-divided into Between students, Academics- 
students' relationship and On higher education institutions. Finally, the paper puts forth conclusions and theoretical and practical implications.

\section{Materials and Methods}

The methodology used in this paper consisted of a meta-analysis of publications that directly focus on this topic currently.

To attain this goal, the favored technique to gather information on the topic under study was document analysis, carried out on different types of document sources, with scientific articles being the main document source. The choice of the article as an empirical field of analysis results from considering that the article is the central formal means of the scientific production and communication process, accounting for the scientific activity of scientists, where argumentative strategies of persuasion are developed and interpretative principles favored by the authors and legitimized by the peers are put forth.

Data collection was based on the consultation of the b-on database of the Foundation for Science and Technology (FCT) in Portugal, an electronic library that includes databases such as the Web of Knowledge, DOAJ (Directory of Open Access Journals) and SCIELO (Scientific Electronic Library Online), among others, as well as institutional repositories (Biblioteca do Conhecimento Online, n.d.). The collection was carried out between July 1 and 16, 2019, through the concurrent search of the following expressions/keywords, both in the Abstract and in the Title: "social media", "Internet" and "higher education". This online bibliographic search was supplemented with the collection of complementary bibliographic material directly related to (re)identity construction, namely in the higher education arena.

\section{Social Media and Identity}

An already classic perspective on identity is the one offered by Claude Dubar (1997). For this author, identity is, ultimately, dependent on how I see myself and how I think others see me. According to the author,

Identity construction is, thus, made in the articulation between the action systems that propose virtual identities and the "lived trajectories", within which the "real" identities that individuals adhere to are forged, and the "lived trajectory" - "designates how individuals subjectively reconstruct the events of their social biography that they deem meaningful", as both a relational and biographical process ( $p$. 108).

Dubar (1997) defines each subject's biographical process as "[...] a construction in time by individuals of social and professional identities" (p. 118). On the other hand, the relational process of an individual refers to the "[...] recognition, at a given moment and within a determined space of legitimation, of the identities associated with knowledge, competences and images of oneself proposed and expressed by individuals in systems of action" (p. 118).

Once identity is defined, although not being unchallengeable, it becomes very difficult to be changed in its main attributes. As stated by Matalon (1990), the effect that new information has on modifying the main identity features is not very relevant when compared with the tendency of the individual towards agreeing with the majority, with the current status quo, in a logic of conformism. However, under particular circumstances, there is, according to Matalon (1990), the possibility that the individual changes his/her attitudes when the conduct of a given minority demonstrates coherence in its stances.

Specifically in terms of the online world, which has profoundly changed how the self is presented to others (Suwinyattichaiporn, 2016; Franchina \& Lo Coco, 2018; Yang, Cao, \& Liao, 2018), Hilsen and Helvik (2012) argue that the various social media channels are both a profound change 
and a challenge in how individuals interact with one another. The authors point to the example of Facebook, which, like other social networks, "[...] open up new possibilities for presentation of the self and of managing the self that one presents to others" (p. 3). Furthermore, as maintained by Golder and Macy (2013) and by Koutamanis, Vossen, and Valkenburg (2015), the impact of online feedback can be more significant than face-to-face feedback for several aspects, mainly their (semi)public and permanent visibility.

Yang et al. (2018) highlight the fact that self-presentation, which is an important component of interpersonal relationships, takes on significantly different contours in the digital and in the more traditional environments, especially in the face-to-face environment. The authors maintain that

Participation in social media proscenium means continuous self-presentation, especially the disclosure of personal private issues is the important part of component to interpersonal relationships. However, self-presentation in social media differs from traditional ways. The new technology enables it is possible to find out personal information and digital traces of social interaction, they have always been displayed and available. Personal information in social media keeps dynamic rather than static. At the same time, compared with self-presentation in the real world on the basis of face-to-face communication, selfpresentation in social media is faced with the fear of performing to unknown person ( $p .83$ ).

Recent online social interactions imply that social networks emerge, for many individuals especially those of the younger generation, who have already been born and raised with them -, as one of the primary elements in the delimitation of their identities, with some mix between the formal and the informal, the private and the public (Serpa \& Ferreira, 2018; Pan, Lu, Wang, \& Chau, 2017). An example of this delimitation in identity construction regards the individual as a higher education student or the construction of his/her professional identity (Kasperiuniene \& Zydziunaite, 2019). These authors state that professional identity obeys two central perspectives: (a) professional identity as a cognitive structure and (b) professional identity as a social construct. In terms of identity construction in a virtual environment, i.e., in social media, it has an increasing influence on the individual's identity framework, since "[...] In modern society, social media communication plays an important role in professional life. [...] [and] People operate and live virtual lives in social networks and online communities" (p. 1).

All this new social configuration brought about by the emergence of social networks has - or should have - implications for the identity construction of higher education as a whole. However, in this context of social media presence (Kasperiuniene \& Zydziunaite, 2019), the scientific literature reveals some tension between social media and higher education institutions. Tess (2013) advocates that "The ubiquity of social media (e.g., Facebook, Twitter) is no more apparent than at the university" (p. 6o).

\section{Social Media and Identity}

According to Kasperiuniene and Zydziunaite (2019), "for academics, it was easier to construct their professional identities when they disassociate their professional and personal lives" (p. 9). The authors further sustain that

Social media has a growing importance in the construction of professional identities in society as it offers places where individuals "showcase" their living and professional experiences. They reflect a variety of attributes regarding individual positions in different professional contexts. It makes people play certain characters in the social and professional arena. Social media enables professional identity expression, exploration, and experimentation (Kasperiuniene \& Zydziunaite, 2019, p. 9).

Akyol and Tanrisevdi (2018), using the work by Dill (1982), advocate that the academic profession involves dealing with the elements depicted in Figure 1, in a context that has specific features. 


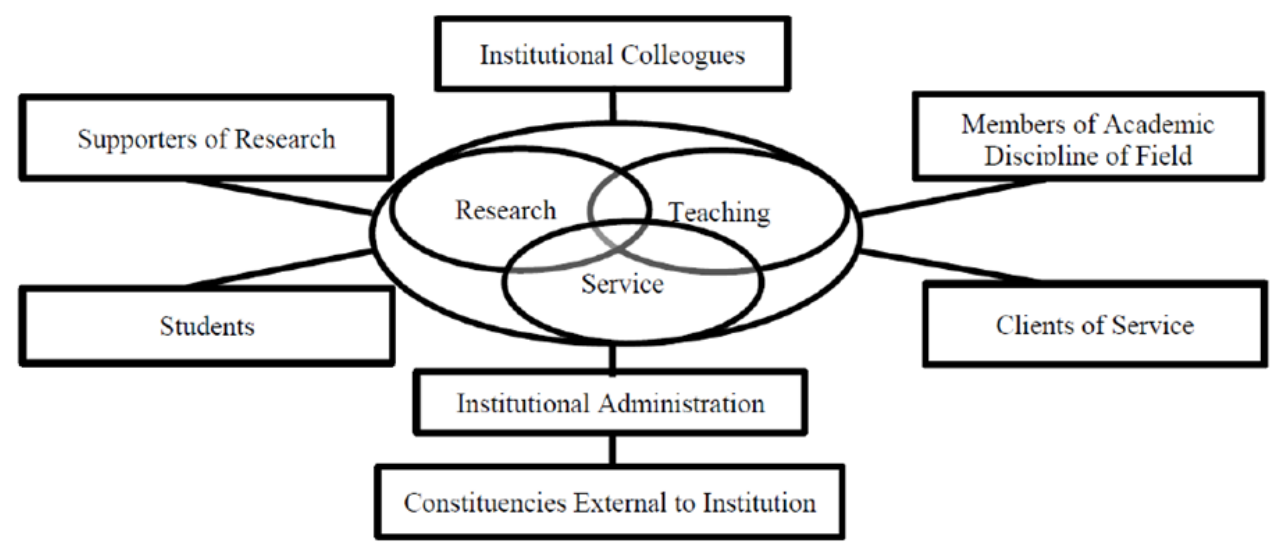

Figure 1. The elements of the academic profession

Source: Dill (1982), cit. in Akyol and Tanrisevdi (2018).

Specifically on the more institutional application of social media, Pasquini and Evangelopoulos (2016) maintain that

As digital communication becomes a fluid part of our lives, an increasing number of colleges and universities are connecting with students, faculty, staff, and alumni on social media. Social technologies offer creative educational opportunities and dynamic learning environments that extend the possibilities of typical education technologies, such as, computer, media, and learning management systems, offer new scenarios for social collaborations and a variety of learner exchanges. Sociotechnical is the interaction between people and technology, specifically as we continue to intertwine technical infrastructures with our social behaviors (p. 219).

\subsection{Between students}

According to Zachos et al. (2018), there is still no empirical evidence that internet social networks exert any kind of influence on higher education students' personality building and, even if it does, whether that influence is positive or negative. In turn, Kim and Kim (2019) argue that social media can significantly shape higher education students' identity, and variables such as gender and ethnicity can influence the way how identity is (re)constructed.

Although the use of digital social networks is widespread among higher education students, some issues should be considered. On the one hand, not all students use them; on the other hand, there are differences in its use, even among young students (Çelebi, Selçuk, \& Peker, 2018; Aleksandrova \& Parusheva, 2019). For example, according to a conclusion of a very interesting study by Keep and Attrill-Smith (2017), "[...] people of different genders may use different self-presentation strategies, but they may be motivated by perception control to the same extent" (p. 562).

According to Thomas, Briggs, Hart, and Kerrigan (2017), the need of these students, without forgetting the specificities of students with disabilities (Pacheco, Lips, \& Yoong, 2018), to simultaneously affirm their identity influenced by a previous community and show loyalty to a new community can be a source of tension. Thus, based on this goal, students manage their online identity. In their 2017 study, Thomas et al. analyze the use of social media by students in the stage between the end of upper secondary education and the enrolment in higher education in relation to the theories of social comparison and community building. According to the proposed model,

Participants move through the stages of affirmation, assimilation and integration similar to other life transitions, but in doing so, we reveal the importance of the intersection between offline and online 
activities and highlight the benefits and limitations of SM [Social Media] use in this transitional period (Thomas et al., 2017, p. 541).

The study by Aleksandrova and Parusheva (2019) confirms the results of previous research, which indicate that students, in their learning process, use various social media tools and channels to communicate with each other and with their teachers. However, students use different channels to communicate with their peers and their teachers. Indeed, "Students use Facebook groups and communication applications (Skype, Viber, etc.) when communicating with their colleagues, while the more preferable channels for communication to their teachers are email and eLMS platforms [...]" (p. 119). The authors also sustain that, in the creation of contents and the teaching-learning process, higher education institutions use primarily "[...] social networking sites, wikis and knowledge base", and stress that "the usage of social media in higher education is mostly initiated by students" (p. 120).

\subsection{The academic-student relationship}

Since the emergence of social media, they have not, for a long time, been viewed individually by academics as possible tools or means that could be put at the service of the teaching-learning process (Stathopoulou et al., 2019; Tess, 2013). Over the past decade, however, these tools have been increasingly accepted by academics and incorporated into their pedagogical strategies, at least at the rhetorical level. In fact, and according to Tess (2013), "[...] instructors look to technology to mediate and enhance their instruction as well as promote active learning for students. Many scholars argue for the purposeful integration of social media as an educational tool" (p. A6o).

However, the empirical evidence of this effective use of social media by academics does not support such an argument (Tess, 2013). Aleksandrova and Parusheva (2019) confirm, in their study, this asymmetry between students and academics regarding the use of social media, noting the much less relevant role of academics in fostering this teaching-learning tool and its use as a form of communication and relationship with their students.

Ferreira and Serpa (2018) warn of the importance of this dialogical relationship (in a broad sense), both between students and between them and academics. The authors argue that

The teacher is unlikely to be an effective teacher-especially at the level of higher education-without complex interactions both between the teacher and the students and between the students. It has long been held that the concept of teaching necessarily entails learning; what is beginning to become evident is that, in practice, the work of the teacher in higher education cannot be satisfactorily understood without a grasp of its related structures of dialogue and communication (p. 8).

Rowan-Kenyon and Alemán (2016) underline the high potential that social media can have in learning by all and for all. Therefore, given that present and future generations of students use social media profusely and very easily, not only to build relationships but to seek produced knowledge, the authors argue that higher education institutions should formalize its use as a tool at the service of the teaching-learning process. According to Rowan-Kenyon and Alemán (2016), "Transforming the way education is delivered is essential to make sure students are able to grasp positive learning experiences while studying in a higher education institution" (p. 16).

Sá and Serpa (2018), Manca and Ranieri (2016), Yavich et al. (2019), Sharma, Joshi and Sharma (2016), Garcia, Moizer, Wilkins, and Haddoud (2019), and Ferreira and Serpa (2018), focusing their attention on higher education, reinforce the importance of practicing a constructivist social education, intentionally active in the development of specific and transversal skills in students. Among transversal skills, digital skills are critical in fostering digital literacy (Santos \& Serpa, 2017; Barrio, 2019). However, this importance is not perceived by all higher education institutions, in particular by their teaching staff. Amin and Rajadurai (2018) critically sustain that higher education institutions appear to have neglected the adoption and promotion of social media in their strategies, both in pedagogical and relational terms. The authors resume the social constructivist current and 
draw attention to the following five elements, advocating their centrality in the learning processes:

1) it is important to have prior experience when reinforcing new learning, 2) during the learning process the learner must participate actively, 3) it is important to negotiate within the learning environment, 4) a social interaction element is required for the construction of an individual's knowledge, and 5) learning arises most effectively in a sociocultural environment (p. 499).

According to Amin and Rajadurai (2018), social media are, potentially - if used intentionally -, an instrument that enables fostering active, collaborative and participatory learning, given that "it is interactive, it engages audiences and enables feedback" (p. 9) (see Table 1).

Table 1. Comparison of the principles of social constructivism and the ideas of social media

\begin{tabular}{l|l|l}
$\begin{array}{l}\text { Traditional Classroom } \\
\begin{array}{l}\text { The curriculum is presented from } \\
\text { the parts to the whole, with an } \\
\text { emphasis on the basic skills. }\end{array}\end{array}$ & $\begin{array}{l}\text { The curriculum is presented in full to the } \\
\text { parties, with an emphasis on the general } \\
\text { concepts. }\end{array}$ & $\begin{array}{l}\text { Active participation and } \\
\text { dynamism. }\end{array}$ \\
\hline $\begin{array}{l}\text { The rigorous follow-up of the pre- } \\
\text { established curriculum is highly } \\
\text { valued. }\end{array}$ & $\begin{array}{l}\text { Search for questions raised by students is } \\
\text { highly valued. }\end{array}$ & Sharing of information \\
\hline $\begin{array}{l}\text { Curricular activities are primarily } \\
\text { based on textbooks and exercises. }\end{array}$ & $\begin{array}{l}\text { The activities are based on primary data } \\
\text { sources and manipulative materials. }\end{array}$ & Communication \\
\hline $\begin{array}{l}\text { Students are seen as "shallow } \\
\text { tables" over which information is } \\
\text { printed. }\end{array}$ & $\begin{array}{l}\text { Students/learners are observed as thinkers } \\
\text { with emerging theories about the world. }\end{array}$ & $\begin{array}{l}\text { Students are given an open } \\
\text { platform to participate and } \\
\text { share experiences. }\end{array}$ \\
$\begin{array}{l}\text { Learning and knowledge are } \\
\text { created through directives. } \\
\begin{array}{l}\text { Evaluation of learning is seen as } \\
\text { distinct from teaching and occurs, } \\
\text { almost entirely, throughout. }\end{array}\end{array}$ & $\begin{array}{l}\text { Evaluation of learning is linked with } \\
\text { teaching and occurs through comments by } \\
\text { the teacher of the students' work. }\end{array}$ & $\begin{array}{l}\text { Information and knowledge are } \\
\text { created by individual } \\
\text { participation. }\end{array}$ \\
\hline
\end{tabular}

Source: Amin and Rajadurai (2018, pp. 504-505).

Amin and Rajadurai (2018) conclude, in their study, that the use of social media in a learning environment "[...] enriches the learning activities of students and facilitates group discussions, and hence, their use should be encouraged in learning and teaching processes in higher education institutions" (p. 59). Thus, based on the results of their study, the authors advocate the promotion of the use of social media in collaborative teaching, in a constructivist social perspective, since it increases the quality of student performance. Moreover, according to Al-Rahmi et al. (2017), "[...] perceived ease of use and perceived usefulness via active collaborative learning with social media use to affect satisfaction and learning performance of [...] students" (p. 5399).

Particularly concerning educational organizations, Stathopoulou et al. (2019) advocate the need for the presence of a specific set of conditions for the use of social media in teaching-learning processes to be fruitful. In their study, the authors conclude that there is a need for

[...] moderators/faculty to be active and knowledgeable of the social media platforms they (intend to) use and post relevant material to encourage students to contribute more and steer discussions in the right direction to avoid inappropriate use from students who simply utilize these platforms for socializing. In the absence of moderation, these platforms may indeed be dominated by "noise," which may potentially undermine students' learning experience. This suggests that educators need to invest considerable time and effort in effectively utilizing social media to support their courses (p. 9).

However, as highlighted by Manca and Ranieri (2016), there are obstacles to the use of social media by academics in their working life in the teaching dimension, such as cultural resistance, 
various pedagogical perspectives not based on social constructivism and possible institutional constraints:

\begin{abstract}
Research has stressed how many teachers require to be sustained by academic administrators, provided with technical and pedagogical guidance and support. Top-down approaches with institution management advising and guiding faculty members would increase their web self-efficacy and compensate their lack of digital competences. At the same time, bottomup approaches, such as identification and sharing of creative teaching practices also suggested by students, could provide the incentive to re-think implicit pedagogies and modify traditional ways of teaching. This would open the way to reconsider certain cultural resistance and shift the focus from unconditional closure towards innovation to more flexible attitudes, which look on Social Media as cultural resources that can be used to improve teaching and learning in contemporary universities (p. 229).
\end{abstract}

But what are the institutional conditions for the implementation of social media as a tool to support the work of academics [17,40], which entails high and "new" involvement of the teacher in the orientation of a fruitful discussion in social media? We will try to answer this question hereafter.

\title{
4.3 On the higher education institution
}

In the context set out above, the implementation of institutional support for teachers, many of whom are doubtful about applying social media in their teaching, is critical, in addition to being a marketing tool for attracting students (Zachos et al., 2018; Stathopoulou et al., 2019; Aleksandrova \& Parusheva, 2019; Brech, Messer, Vander Schee, Rauschnabel, \& Ivens, 2016; Fujita, Harrigan, \& Soutar, 2018).

As highlighted by Fujita et al. (2018) regarding organisational culture and organisational identity, the culture of an institution, regardless of its kind, should promote the co-creation of its identity by all its stakeholders. The authors argue that "Facilitating meaningful customer experiences is about ensuring congruence between customer identities and brand and organizational identities, and it is here that social media has an important role to play" (p. 68).

Rowan-Kenyon and Martínez Alemán (2016) believe that the widespread use of social media by higher education institutions and their incorporation into teaching-learning processes, together with the relationship between all institutional actors, will dictate the future of social media themselves, since the way how "[...] social media evolve in the marketplace will affect how college students, staff, administrators, and faculty employ these media on campus in and outside the classroom" (p. 108). On the other hand, it seems safe to state, in agreement with Rowan-Kenyon and Martínez Alemán (2016), that future leaders and professionals of higher education institutions, now students completely immersed in new technologies and permanent users of social media, will advocate the use of these tools inside and outside the classroom, that is, both in formal learning processes and in building relationships between the various institutional actors.

In the same vein, Peruta and Shields (2016) sustain that

At a time when universities are facing increasing competition to attract and retain the best students, social media is seen as a more viable method of communication between the institution and its constituents, including current students, prospective students, parents, alumni, and community members (p. 131).

In summary, and according to Donelan (2015), "The main barriers to using social media were identified as a lack of time and skills to undertake these activities, as well as a negative perception of social media". To these, the author adds the scientific field, faculty's age and seniority, knowledge and experience of digital skills should be considered in this process of fostering the use of social media in higher education. Thus, Donelan (2015) suggests that

\section{[...] if higher education institutions are willing their faculty staff to update their teaching practices with}


the support of new technologies, recognition and estimation of time spent on teaching are both necessary, whatever technological solutions are adopted. [...] We could say that Social Media fit well with the common practices that academics are used to enacting to disseminate their ideas and build their public profile. However, the overlapping of personal and professional lives might be a threat, as the preference of more experienced scholars for professional Social Media suggests ( $p .73)$.

\section{Conclusion}

Although most studies sustain that the mobilization of social networks for educational purposes has high potential (Zachos et al., 2018), it seems that it is still necessary to implement the idea conveyed by Manca and Ranieri (2016), who advocate that "Social Media are playing a marginal role in academic life" (p. 229).

According to the study by Zachos et al. (2018), students that use social networks show improved self-esteem, higher peer acceptance and better cognitive language skills. However, there are some activities in social networks that make its use a criticized learning tool, such as chatting and online games, to the detriment of information research and study support tool.

Waycott, Thompson, Sheard, and Clerehan (2017) also point out some aspects to consider, namely regarding the scrutiny, by a community of practice, of the work that students make public on the social web. The authors argue that "When using social web technologies for university assignments, students may feel as though they are constantly under surveillance by authority figures (i.e., teachers), peers, and unknown 'others'” (p. 19). Waycott et al. (2017) argue that sharing students' work on the Internet can have negative and positive results. While, on the one hand, this form of work-sharing may foster the development of a unified learning community, on the other hand, it may generate anxiety and pressure on students to understand how their participation and performance of identity is perceived by the other community members. Considering these resistances, students choose how much information they want to share with their peers. However, this study by Waycott et al. (2017) demonstrated that some students are concerned with the "[...] reified persona the lecturer might be left with at the end of these assignments, which involved not only sharing students' work, but also in some cases engaging in personal (yet public) reflections" (p. 19). In this line, regarding the influence of social media use on body image concerns, Franchina and Lo Coco (2018) argue that "Media content does not mirror the reality, nevertheless the promulgated content becomes the standard against which the self and the others are judged" (p. 7).

In short, social media play and can play a central role in students' lives, both inside and outside the classroom. Consequently, and given the reality of the present generation and the way it interacts with the world, higher education institutions have to incorporate social media into their systems. This can be done, for example, "By building online structures that have these new realities embedded within their architecture” (Rowan-Kenyon \& Alemán, 2016, p. 111). By doing so, higher education institutions will convey to their current and potential students the image that they have digital skills and promote this type of interaction, which will add to the improvement of their performance and satisfaction. According to Stathopoulou et al. (2019),

All of the above benefits of social media in learning, including the co-creation of knowledge, facilitation of different learning styles, promotion of experiential learning, and enhancement of collaborative skills, provide evidence that social media can be an effective tool in learning, both in delivering and assessment of different courses in management studies (p. 4).

While higher education institutions "[...] will never be ahead of the social media curve, [...] they will best serve their constituents by evolving their practices and policies with social media as their capabilities are enhanced and enriched" (Rowan-Kenyon \& Alemán, 2016, p. 111). 


\section{Acknowledgements}

University of The Azores, Interdisciplinary Centre of Social Sciences-CICS.UAc/CICS.NOVA. UAc, UID/SOC/04647/2013, with the financial support of FCT/MEC through national funds and, when applicable, co-financing from FEDER under the PT2020 Partnership Agreement.

\section{References}

Akyol, B., \& Tanrisevdi, F. (2018). Academicians in Turkey: An evaluation of current status of academic staff in higher education. Higher Education Studies, 8(4), 129. doi: 10.5539/hes.v8n4p129.

Aleksandrova, Y. G., \& Parusheva, S. S. (2019). Social media usage patterns in higher education institutions - An empirical study. International Journal of Emerging Technologies in Learning, 14(05), 108. doi: 10.3991/ijet.v14io5.9720.

Al-Rahmi, W. M., Alias, N.; Othman, M. S., Ahmed, I. A., Zeki, A. M., \& Saged, A. A. (2017). Social media use, collaborative learning and students' academic performance: A systematic literature review of theoretical models. Journal of Theoretical and Applied Information Technology, 95(20), 5399-5414.

Amin, A., \& Rajadurai, J. (2018). The conflict between social media and higher education institutions. Global Business and Management Research: An International Journal, 10(3), 499-510.

Barrio, R. (2019). Technology, socioeconomics and education. International Journal of Advanced Corporate Learning, 12(1), 67. doi: 10.3991/ijac.v12i1.9264.

Bernardini, J. (2019). Nomophobia: A research among Italian digital natives. Journal for Social Media Inquiry, 1(1), 1-10. doi: 10.18662/jsmi/o1.

Biblioteca do Conhecimento Online (n.d.). What is b-on? [Online] Available: https://www.b-on.pt/en/what-is-bon/ (July 1, 2019).

Brech, F. M., Messer, U., Vander Schee, B. A., Rauschnabel, P. A., \& Ivens, B. S. (2016). Engaging fans and the community in social media: interaction with institutions of higher education on Facebook. Journal of Marketing for Higher Education, 27(1), 112-130. doi: 10.108o/o8841241.2016.1219803.

Çelebi, N., Selçuk, G., \& Peker, H. S. (2018). A study on the use of social networks by Turkish and German university students in the globalization process. Journal of Education and Training Studies, 6(11a), 88. doi: 10.11114/jets.v6i11a.3804.

Chugh, R., \& Ruhi, U. (2017). Social media in higher education: A literature review of Facebook. Education and Information Technologies, 23(2), 605-616. doi: 10.1007/s10639-017-9621-2.

Dill, D. (1982). The structure of the academic profession: Toward a definition of ethical issues. The Journal of Higher Education, 53(3), 255-267. doi: 10.1080/o0221546.1982.11780452.

Donelan, H. (2015). Social media for professional development and networking opportunities in academia. Journal of Further and Higher Education, 40(5), 706-729. doi: 10.1080/0309877x.2015.1014321.

Dubar, C. (1997). A socialização. Construção das identidades sociais e profissionais [Socialisation. Construction of social and professional identities]. Porto: Porto Editora.

Ferreira, C. M., \& Serpa, S. (2018). Society 5.0 and social development: Contributions to a discussion. Management and Organizational Studies, 5(4), 26. doi: 10.5430/mos.v5n4p26.

Franchina, V, \& Lo Coco, G. (2018). The influence of social media use on body image concerns. International Journal of Psychoanalysis and Education, X(1), 5-14.

Fujita, M., Harrigan, P., \& Soutar, G. N. (2018). Capturing and co-creating student experiences in social media: A social identity theory perspective. Journal of Marketing Theory and Practice, 26(1-2), 55-71. doi: 10.1080/10696679.2017.1389245.

Garcia, E., Moizer, J., Wilkins, S., \& Haddoud, M. Y. (2019). Student learning in higher education through blogging in the classroom. Computers \& Education, 136, 61-74. doi: 10.1016/j.compedu.2019.03.011.

Gladden, M. E. (2019). Who will be the members of Society 5.0? Towards an anthropology of technologically posthumanized future societies. Social Sciences, 8(5), 148. doi: 10.339o/socsci8050148.

Golder, S. A., \& Macy, M. W. (2013). Social media as a research environment. Cyberpsychology, Behavior, and Social Networking, 16(9), 627-628. doi: 10.1089/cyber.2013.1525.

Hashim, K. F., Rashid, A., \& Atalla, S. (2018). Social media for teaching and learning within higher education institution: A bibliometric analysis of the literature (2008-2018). International Journal of Interactive Mobile Technologies, 12(7), 4. doi: 10.3991/ijim.v12i7.9634.

Hilsen, A. I., \& Helvik, T. (2012). The construction of self in social medias, such as Facebook. AI \& Society, 29(1), 31o. doi: 10.1007/soo146-012-0426-y. 
Kasperiuniene, J., \& Zydziunaite, V. (2019). A systematic literature review on professional identity construction in social media. SAGE Open, 9(1), 1-11. doi: 10.1177/2158244019828847.

Keep, M., \& Attrill-Smith, A. (2017). Controlling you watching me: Measuring perception control on social media. Cyberpsychology, Behavior, and Social Networking, 20(9), 561-566. doi: 10.1089/cyber.2017.0040.

Kelling, N. J., Kelling, A. S., \& Lennon, J. F. (2013). The tweets that killed a university: A case study investigating the use of traditional and social media in the closure of a state university. Computers in Human Behavior, 29(6), 2656-2664. doi: 10.1016/j.chb.2013.06.044.

Kim, B., \& Kim, Y. (2019). Growing as social beings: How social media use for college sports is associated with college students' group identity and collective self-esteem. Computers in Human Behavior, 97, 241-249. doi: 10.1016/j.chb.2019.03.016.

Koutamanis, M., Vossen, H. G. M., \& Valkenburg, P. M. (2015). Adolescents' comments in social media: Why do adolescents receive negative feedback and who is most at risk? Computers in Human Behavior, 53, 486-494. doi: 10.1016/j.chb.2015.07.016.

Longstreet, P., \& Brooks, S. (2017). Life satisfaction: A key to managing internet \& social media addiction. Technology in Society, 50, 73-77. doi: 10.1016/j.techsoc.2017.05.003.

Manca, S., \& Ranieri, M. (2016). Facebook and the others. Potentials and obstacles of social media for teaching in higher education. Computers E Education, 95, 216-230. doi: 10.1016/j.compedu.2016.01.012.

Matalon, B. (1990). Atitude. In R. Boudon, P. Besnard, M. Cherkaoui, \& B.-P. Lécuyer (Dirs.), Dicionário de sociologia [Dictionary of sociology] (pp. 21-22). Lisboa: Publicações Dom Quixote.

Pacheco, E., Lips, M., \& Yoong, P. (2018). Transition 2.0: Digital technologies, higher education, and vision impairment. The Internet and Higher Education, 37, 1-10. doi: 10.1016/j.iheduc.2017.11.001.

Pan, Z., Lu, Y., Wang, B., \& Chau, P. Y. K. (2017). Who do you think you are? Common and differential effects of social self-identity on social media usage. Journal of Management Information Systems, 34(1), 71-101. doi: 10.1080/o7421222.2017.1296747.

Pasquini, L. A., \& Evangelopoulos, N. (2016). Sociotechnical stewardship in higher education: A field study of social media policy documents. Journal of Computing in Higher Education, 29(2), 218-239. doi: 10.1007/s12528-016-9130-0.

Peruta, A., \& Shields, A. B. (2016). Social media in higher education: Understanding how colleges and universities use Facebook. Journal of Marketing for Higher Education, 27(1), 131-143. doi: 10.1080/08841241.2016.1212451.

Rashid, U. K., Ahmed, O., \& Hossain, M. A. (2019). Relationship between need for belongingness and Facebook addiction: Mediating role of number of friends on Facebook. International Journal of Social Science Studies, 7(2), 36. doi: 10.11114/ijsss.v7i2.4017.

Rowan-Kenyon, H., \& Alemán, A. M. (2016). Social media in higher education. ASHE Higher Education Report, 42, 5. San Francisco: Jossey-Bass.

Sá, M., \& Serpa, S. (2018). Transversal competences: Their importance and learning processes by higher education students. Education Sciences, 8(3), 126. doi: 10.3390/educsci8030126.

Santos, A. I., \& Serpa, S. (2017). The importance of promoting digital literacy in higher education. International Journal of Social Science Studies, 5(6), 90. doi: 10.11114/ijsss.v5i6.2330.

Serpa, S., \& Ferreira, C. M. (2018). Goffman's backstage revisited: Conceptual relevance in contemporary social interactions. International Journal of Social Science Studies, 6(10), 74. doi: 10.11114/ijsss.v6i10.3659.

Sharma, S. K., Joshi, A., \& Sharma, H. (2016). A multi-analytical approach to predict the Facebook usage in higher education. Computers in Human Behavior, 55, 340-353. doi: 10.1016/j.chb.2015.09.020.

Stathopoulou, A., Siamagka, N.-T., \& Christodoulides, G. (2019). A multi-stakeholder view of social media as a supporting tool in higher education: An educator-student perspective. European Management Journal, 37(4), 421-431. doi: 10.1016/j.emj.2019.01.008.

Suwinyattichaiporn, T. (2016). Project me: Understanding social identities through social media. Communication Teacher, 30(3), 179-183. doi: 10.1080/17404622.2016.1192664.

Taylor \& Francis (2019). Exploring the digital landscape in higher education. 5 steps to making the most of technology inside and outside the classroom. A White Paper. [Online]. Available: https://www.crcpress.com/rsc/downloads/WP-Exploring\%2Bthe\%2BDigital\%2BLandscape.pdf (July 20, 2019).

Tess, P. A. (2013). The role of social media in higher education classes (real and virtual) - A literature review. Computers in Human Behavior, 29(5), A6o-A68. doi: 10.1016/j.chb.2012.12.032.

Thomas, L., Briggs, P., Hart, A., \& Kerrigan, F. (2017). Understanding social media and identity work in young people transitioning to university. Computers in Human Behavior, 76, 541-553. doi: 10.1016/j.chb.2017.08.021. 
Throuvala, M. A., Griffiths, M. D., Rennoldson, M., \& Kuss, D. J. (2019). Motivational processes and dysfunctional mechanisms of social media use among adolescents: A qualitative focus group study. Computers in Human Behavior, 93, 164-175. doi: 10.1016/j.chb.2018.12.012.

Watts, L. K., Wagner, J., Velasquez, B., \& Behrens, P. I. (2017). Cyberbullying in higher education: A literature review. Computers in Human Behavior, 69, 268-274. doi: 10.1016/j.chb.2016.12.038.

Waycott, J., Thompson, W., Sheard, J, \& Clerehan, R. (2017). A virtual panopticon in the community of practice: Students' experiences of being visible on social media. The Internet and Higher Education, 35, 12-20. doi: 10.1016/j.iheduc.2017.07.001.

Yang, M., Cao, C., \& Liao, H. (2018). Social media privacy concerns and self presentation. 2018 International Joint Conference on Information, Media and Engineering (ICIME). Osaka, Japan, December 12-14. doi: 10.1109/icime.2018.00026.

Yavich, R., Davidovitch, N., \& Frenkel, Z. (2019). Social media and loneliness - Forever connected? Higher Education Studies, 9(2), 10. doi: 10.5539/hes.v9n2p1o.

Zachos, G., Paraskevopoulou-Kollia, E.-A., \& Anagnostopoulos, I. (2018). Social media use in higher education: A review. Education Sciences, 8(4), 194. doi: 10.3390/educsci8040194. 